\title{
Erratum to: Robust optimization of the rate of penetration of a drill-string using a stochastic nonlinear dynamical model
}

\author{
T. G. Ritto - C. Soize - R. Sampaio
}

Published online: 30 January 2010

(c) Springer-Verlag 2010

Erratum to: Comput Mech

DOI 10.1007/s00466-009-0462-8

Unfortunately the second author name was published with an error. The correct author name is given below:

C. Soize

The online version of the original article can be found under doi:10.1007/s00466-009-0462-8.

T. G. Ritto $(\varangle) \cdot$ R. Sampaio

Department of Mechanical Engineering, PUC-Rio, Rua Marquês

de São Vicente, 225, 22453-900 Rio de Janeiro, Brazil

e-mail: thiagoritto@gmail.com

R. Sampaio

e-mail: rsampaio@puc-rio.br

T. G. Ritto · C. Soize

Laboratoire de Modélisation et Simulation Multi-Echelle, MSME,

Université Paris-Est, FRE3160 CNRS, 5 bd Descartes,

77454 Marne-la-Vallée, France

e-mail: christian.soize@univ-paris-est.fr 